\title{
Miranda
}

Revue pluridisciplinaire du monde anglophone /

Multidisciplinary peer-reviewed journal on the English-

speaking world

23 | 2021

Modernist Exceptions

\section{Conference Report: 26th SERCIA Conference: "Cosmopolitan Aspirations in English-Speaking Cinema and Television"}

Universidad de Zaragoza, Zaragoza, Spain, September 8-10 2021. Conference organized by Maria del Mar Azcona, Julia Echeverría, and Pablo Gómez

\section{Costanza Salvi and Marine Soubeille}

\section{OpenEdition}

\section{Journals}

Electronic version

URL: https://journals.openedition.org/miranda/41228

DOI: 10.4000/miranda.41228

ISSN: 2108-6559

\section{Publisher}

Université Toulouse - Jean Jaurès

\section{Electronic reference}

Costanza Salvi and Marine Soubeille, "Conference Report: 26th SERCIA Conference: "Cosmopolitan Aspirations in English-Speaking Cinema and Television"', Miranda [Online], 23 | 2021, Online since 11 October 2021, connection on 29 November 2021. URL: http://journals.openedition.org/miranda/41228 ; DOI: https://doi.org/10.4000/miranda.41228

This text was automatically generated on 29 November 2021.

\section{cc)}

Miranda is licensed under a Creative Commons Attribution-NonCommercial-NoDerivatives 4.0 International License. 


\section{Conference Report: 26th SERCIA Conference: "Cosmopolitan Aspirations in English-Speaking Cinema and Television"}

Universidad de Zaragoza, Zaragoza, Spain, September 8-10 2021. Conference organized by Maria del Mar Azcona, Julia Echeverría, and Pablo Gómez

\section{Costanza Salvi and Marine Soubeille}

1 SERCIA (Société d'Études et de Recherche sur le Cinéma Anglophone), a research group founded in 1993 to gather researchers in the field of English-speaking cinema and television, held its $26^{\text {th }}$ conference in September 2021 at Universidad de Zaragoza, Spain. Originally meant to take place in 2020, the Conference was postponed due to the Covid-19 pandemic, which forced the organizers, Marimar Azcona, Julia Echeverría, and Pablo Gómez of the Department of English and German Philology of the University of Zaragoza, to organize the conference in a hybrid format (in person and on-line). The three-day conference was held at the modern Centro Joaquín Roncal and included 21 panels and two impressive plenary lectures by Deborah Shaw (University of Portsmouth) and Juan Antonio Suárez (Universidad de Murcia).

2 This conference theme, "Cosmopolitan Aspirations," focused on cosmopolitanism. A philosophical concept with a long tradition (Diogenes, Kant), its contemporary usage invites scholars to reflect on the social, political, economic, and cultural consequences of the increased mobility of goods and people in a globally connected world. On the one hand, analyses stressed the positive aspects linked to the broadening of the moral and political horizons of a given community through the values of inclusion; on the other, a great number of talks focused on adverse outcomes, including the homogenization produced by global markets or the proliferation of global risks. Other talks emphasized the limits of the concept. Taking its roots in Ancient Greece, as the concept of Ecumene may attest, cosmopolitanism became especially appealing in the 1990s, with the fall of 
the Berlin Wall and the end of apartheid, and later, with the widespread use of the Internet and the emergence of network society. As a result, the majority of papers focused on contemporary cinema, TV series, franchises, arts, media, and cultures, while a few offered in-depth analyses of silent and classical films. Some talks pinpointed specific genres (science fiction, the Western, horror, comedy, as well as talk shows and documentaries) spreading across different countries and geographical contexts, tackling the transnational nature of cosmopolitan representations; others emphasized specific approaches, areas of interests, and methodologies such as cosmopolitan identity and places (whether global cities or borderlands), ecological visions, cosmopolitan celebrities and stars, issues related to mobility, co-productions, and global reception. It should be noted that, because of the physical impossibility for the authors to attend all the panels happening at the same time, this conference report could not cover the entirety of the communications presented during the three days.

The opening keynote, "Cosmopolitan Materiality and the Queer Archive: Glitter in 70s Underground Cinema," by Juan Antonio Suárez, insisted on the importance of dealing with the material quality of cosmopolitanism, usually conceived in its abstract traits. Suárez argued that the spread of glitter in fashion, art, performance, pop music, and underground film during the sixties and seventies offered the "hardware" of a cosmopolitan attitude based on mobility, spatial and social border-crossing; it contributed to the creation of a queer community through the appropriation of shine/ glimmer. He outlined the origin of the glitter trend in cosmetics and fashion, and then moved to French haute couture and to avant-garde architecture and design, explaining how, more than a trend, this passion for light and glitter had come to represent a new sexual freedom; it became a symbol of alternative lifestyles as the expression of dynamic, energetic hedonism and social mobility. This vision, which was connected to a sensibility toward Exoticism and Orientalism, allowed the materiality of glitter to acquire the value of a "cosmopolitan embrace," as illustrated by queer experimental cinema from US-American and European filmmakers such as Jack Smith (Jungle Island, 1967) and Steven Arnold (Luminous Procuress, 1971) in the US; Stéphane Marti (La cité des neuf portes, 1977) and Teo Hernández (who was of Mexican origin) in France; Carlos Comas (Fosca, 1977) in Spain. All these artists used glitter to express their provocative ideas of a fluid material art producing erotically and spiritually charged tableaux where body, textile and plastic matters were not only an iconic imaginary, but acted as an idiosyncratic liberation from conventional expressions. Glitter promoted a style of representation that preferred diffused color and light rather than distinct shapes to express a cosmopolitan aspiration toward a transnational community, to be found beyond the limits of the male/female binary.

4 The panel dedicated to "Cosmopolitan Stars and Celebrities" focused on actresses Ingrid Bergman, Diane Kruger and Viveca Lindfors. Celestino Deleyto (Vice-president of SERCIA, Universidad de Zaragoza) analyzed the transnational career of Diane Kruger, opening with a discussion of the theoretical background behind the two often overlapped concepts of "transnational" and "global." For Deleyto, transnationalism should be understood as the geographical specificity of the intersection of local cultures and international movements, while the term "global" holds much more depreciative connotations (loss of one's identity, erasure of the inequalities between countries). Deleyto identified Kruger as, simultaneously, a transnational and global star anchored in several different nationalities (being a German, French, and US citizen), but also representing the global abstraction articulated in her flawless white skin and 
translucent femininity. The peculiarity of Kruger as a transnational/global star, he argued, typifies the contradiction of a disunited Europe unable to cope with a lack of tolerance and solidarity. Sara Pesce (Università di Bologna) analyzed the figure of Ingrid Bergman as a half German, half-Swedish star, displaying a talent for crossing borders, both in terms of geography and cultural standards. Pesce showed how the actress gradually strayed from the image of a righteous woman linked to an ideal homeland that David O. Selznick had arranged for her since Intermezzo (Gregory Ratoff, 1939) and used the case study of Autumn Sonata (Ingmar Bergman, 1978) as a point of arrival of the ambiguity of the ideological construction of the star's image, displaying a tension between transnational aspirations and the duties of homeland protection. Saki Kobayashi (Stockholms Universitet) then focused on the star persona of Viveca Lindfors, as a Swedish actress characterized by a strong mark of cosmopolitanism; Kobayashi discussed the tensions between the US conception of the Swedish national identity and the Swedish conception of the self, as they appear in media discourses on Swedish stars within, beyond, and across borders.

In the panel entitled "Languages and Translation," Isabelle Schmitt-Pitiot (Université de Bourgogne, Dijon) opened the discussion on cinema dubbing and language issues with a comparison between Inglorious Basterds (Quentin Tarantino, 2009) and A Hidden Life (Terence Malick, 2019), and the way the two contemporary war films had chosen to treat foreign languages for their audience, and the ideological consequences those choices bore. Analyzing the war film as a genre in which understanding can be a vital matter, Schmitt-Pitiot showed how choosing not to translate an original language could better reveal the character's ordeal and bet on the audience's adaptability. Yet, whether these choices allow a provocative commentary on translation biases (Tarantino) or constitute a plea for a cosmopolitan, multilingual cinema (Malick), they might appear to exclude certain types of audiences while constituting an attempt at proving the universal quality of cinema. Sophie Chadelle (Université Toulouse Jean Jaurès) discussed the impact of translation choices of the series Ugly Betty (ABC, 2006), adapted from the Colombian telenovela Yo Soy Betty, La Fea (RCN Television, 1999-2001), which introduces a young Mexican-American woman to the world of New York fashion. Paying special attention to a sequence in which Betty is implicitly compared to the Latina sex-symbol Shakira through the use of one of her songs, Chadelle tackled the biases underlying the official French dubbing of the series, which, by failing to subtitle or translate the lyrics of the song, deprived the scene of the comment it makes on the vision of Latina women by US-American audiences. For Chadelle, the loss of a feminist subtext is frequent in French translations of contemporary TV series. In the same panel, Antonio Terrón Barroso (Aston University, Birmingham) then offered to share the results of his research on the geographical and semantic representations of Spaniards in American, British and Spanish coproductions and in the online reviews of those films. He analyzed the semantic fields used in those reviews to give a sense of how Spanish-speaking figures and characters in the cinema were represented in the collective, international imaginary and how the stereotypes attached to them concurred or shifted from one country to the other.

6 The "Post-feminism and Geography" panel opened with Ahngeli Shivam's (Johannes Gutenberg University-Georgia State University) discussion of the work of Mindy Kaling, who created and starred in the sitcom The Mindy Project (Fox-Hulu, 2012-2017). Shivam employed cosmopolitan elements to magnify a form of onscreen diversity, thereby casting new light on mainstream prejudices and exclusionary practices. Through a mix 
of particular concerns and universal interrogations, Mindy Kaling, according to Shivam, was able to re-orient the oppressive ways in which women are seen in a transnational context serving as a fictive place for a peaceful and unstated rebellion. The next speaker, Isabel Trevino López (Universidad de Zaragoza), identified in Steven Soderbergh's 2011 film Contagion the biases still linked to the persistence of two different images of cosmopolitan women. She analyzed, on the one hand, the character played by Gwyneth Paltrow, who embodies the traditionally male figure of the frequent flyer, and on the other, the characters played by Marion Cotillard and Kate Winslet, as incarnating a feminine definition of cosmopolitan openness, caregiving solidarity, and self-sacrifice. Trevino López further pointed out the usual negative connotations ascribed to the first kind of cosmopolitan women, championing the latter as the correct one. Finally, Negar Sadeghian (Universidad Carlos III Madrid) centered her talk on the social and political changes which occurred after the Islamic revolution in 1979, arguing that the empowerment of women negotiating the notion of modern femininity against the core of the Iranian government allowed many feminist directors in Iran to build up a paradigm of national identity together with the formation of a national cinema.

7 The notions of borders and border-crossing, central to the discussion of cosmopolitanism as a potentially hybrid cultural space, was tackled by no less than five different panels and around fourteen panelists over the three days, encompassing different methodologies, epochs and film genres. In the first of those panels centered on "Transcending Borders," Carla Francellini (Universita Di Siena) discussed how the various border-crossings in John Ford's Grapes of Wrath (1940) gradually changed the characters' relation to their environment and created a cosmopolitan yet socially determined community; Francellini argued that these geographical, emotional and physical crossings enhanced the tensions between the individual and the community by depriving their characters of identity and forcing them to create a new one. Dispossession and the recreation of cosmopolitan identity were similarly emphasized by Yann Roblou (Université Polytechnique des Hauts de France) in his comparison of the consequences of exile and alienation on the characters of Terence Malick's The New World (2005) and Nicholas Winding Refn's Valhalla Rising (2009); Roblou demonstrated how, through the use of different techniques, the two directors disorient their characters and audience in order to figure the difficult quest for identity at stake in both films.

8 The "Cross-Border Interactions" panel was the second to deal with the notion of borders, with speakers examining transnational exchanges and cosmopolitan encounters across different national borders. Philip Drummond (New York University in London) tackled the subject of the Italian villa narratives in a group of British films in which British women are transferred to Italian mansions and find themselves changed or challenged by new intercultural encounters; Drummond argued that films like The Battle of the Villa Fiorita (Delmer Daves, 1965), My House in Umbria (Richard Loncraine, 2003) and Enchanted April (Mike Newell, 1991) expressed a nostalgic readaptation of the transformative power represented by the architectural spaces of Italian villas in 19th century Grand Tour, while offering a counterpoint to contemporary debates over identity in the UK and its decoupling from the European Union. Janica Tomic (University of Zagreb) proposed an analysis of Scandinavian cinema through three key elements offered by the Deleuzian concept of "minor," a term used to emphasize the deterritorialization, the political background, and the 
collective aspects of Eastern European literature, and applied by Tomic to the analysis of Reprise (Joachim Trier, 2006) as an exemplar of contemporary Norwegian art cinema that continues to subvert the myths of national identity on screen, inviting to cosmopolitan encounters. Matt Wanat (Ohio State University) then discussed Sam Fuller's Dead Pigeon on Beethoven Street (1972) as a transnational exploration of different film genres, intradiegetic performances, and self-reflexivity, acting as a cosmopolitan masquerade of cross-cultural references to French, US-American, and German films and world cultures; Wanat argued that the film showed the limits of a transnational politics as well as the limits of the global meaning attributed to Fuller's cinema. Finally, Bram Van Beek (Universiteit Antwerpen) reflected on the ambiguity of cosmopolitanism in a refugee context and, focusing on Problemski Hotel (Manu Riche, 2015), analyzed the specific condition of the refugees and their "marginal cosmopolitanism" within the hybrid and bilingual Belgian culture.

Meanwhile, in the panel dedicated to "Ecological Visions," Christophe Gelly (Université de Clermont Auvergne) proposed a comparative study of Blade Runner (Ridley Scott, 1982) and Blade Runner 2049 (Denis Villeneuve, 2017), with special attention to the spatial representation of Asian cities as quintessential cosmopolitan spaces; within the cross-cultural references offered by these two films, Gelly questioned the stereotypical image of Asian cities offering harmonious coexistence between diverse ethnicities through the films' chaotic clash of conflicting motifs. Katarzyna Paszkiewicz (University of the Balearic Islands) then focused on Geostorm (Dean Devlin, 2017) in relation to human responses to ecological crises; she argued that the film questions the hegemonic role of the US in the globalization, but also reinforces the confidence in techno-scientific signs of progress, failing to manifest Ursula K. Heise's (2008) ideal "eco-cosmopolitanism." Ana Virginia López Fuentes (Universidad de Zaragoza) engaged with similar notions in the Pixar animated film WALL-E (Andrew Stanton, 2008), with special attention to the way popular trust in technology was expected to elicit cosmopolitan encounters. Finally, Mónica Martín (Universidad de Zaragoza) offered an analysis of The East (Zal Batmanglij, 2013) as an instance of eco-cosmopolitanism based on an ethics of care and ecological sustainability, contrasting with the anthropocentric and economized paradigms of profit-driven rationality.

The "Cosmopolitan Laughs" panel explored the theme of cosmopolitanism in comedy. Peter Templeton (Loughborough University) compared the representations of cosmopolitanism in the TV series Brooklyn Nine-Nine (Fox, 2013-2021) and The Good Place (NBC, 2016-2020) analyzing how the two shows pictured minorities in their casts and characters or by imagining an international afterlife. The second panelist, Beatriz Oria Gomez (Universidad de Zaragoza) discussed the dilemma provoked by a globalized social media market of match-making, and the Western ideal of soul mates in the series Master of None (Netflix, 2015-). The two following talks by David Lipson (Universite de Strasbourg) and Olivera Tesnohlidkova (Masaryk University) offered a genealogy of the cosmopolitan influence of two American Late-Night shows, The Daily Show with John Stewart (Comedy Central, 1999-2015) and Last Week Tonight with John Oliver (Comedy Central, 2014-). Lipson argued about the transnational consequences of the model set by John Stewart's particular style, and questioned the impact of the foreign sequels of the show. Tesnohlidkova analyzed the comic processes used by John Oliver so as to familiarize and sensibilize his audience with cosmopolitan or foreign matters. 
11 In the third panel devoted to borders, "Borders Yesterday and Today," speakers focused on possible parallels between the images of borderland in past and present cinema. Gilles Menegaldo's (Université de Poitiers) analyzed the border motif in Frozen River (Courtney Hunt, 2008); he argued that the film revealed numerous issues, such as deep-rooted prejudices, destitution, and alienation while, ultimately, the various border-crossings enabled some sort of understanding and solidarity to emerge, allowing the two protagonists to bond in spite of their differences. While Menegaldo's talk dealt with the US-Canadian border, the three other speakers offered a variety of analysis of the US-Mexican border. Costanza Salvi (Universidad de Zaragoza) focused on Budd Boetticher's films as a case study within a larger research project on the representation of the US-Mexico border in Classical Westerns, in light of a cosmopolitan sensibility declined in the transnational relationship between Mexico and the US. Drawing on Gerard Delanty's emphasis on the cultural framework of cosmopolitanism, Salvi highlighted that the US-Mexican borderland was not a dividing line opposing two completely different political and economic systems, but a border zone where forms of cultural hybridity and geographical commonalities were often detectable, taking Boetticher's films as instances of this kind of exchange, mostly in Buchanan Rides Alone (Budd Boetticher, 1958). A similar view of the borderland as a place of cultural hybridity and cosmopolitan informed Marine Soubeille's (Université Paul Valéry Montpellier 3) discussion of Tejano, a 2018 independent film directed by a Texan-Mexican director, David B. Garcia; her analysis revealed that even though the borderland was de facto a place of cultural exchange and identity (as postulated by Cooper and Rumford, 2011), due to a long common history, it remained to this day a place of ideological conflict between two nations in the name of which an internal war is still waged on a daily basis. Xavier Daverat (Université de Bordeaux) gave a talk in French about a collection of poems by Tino Villanueva, a Chicano poet who wrote about his experience of the screening of the movie Giant (George Stevens, 1956) when he was a boy; Daverat's elegant analysis of the collection's style and rhythm revealed the traumatic experience of the poet regarding the movie's depiction of racism and Latino discrimination.

In the panel on "Post-Western Perspectives," Glenn Man (University of Hawaii) examined the notions of indigeneity and hybridity in Drunktown's Finest (Sydney Freeland, 2014) and The Body Remembers When the World Broke Open (Elle-Máijá Tailfeathers, 2019), two indigenous North-American narratives, from a postcolonial perspective; he focused on the multiple narratives each movie set and their constant border crossing, questioning cosmopolitanism in relation to native populations' assimilation and resistance. Mikaël Toulza (Université Toulouse Jean Jaurès) analyzed the reactionary figure of James Bond in Live and Let Die (Guy Hamilton, 1973) as an instance of "cosmopolitanized voodooism". In spite of the film's cosmopolitan setting (New York, San Monique and New Orleans), which allows the main character to cross borders easily, Toulza underscored the movie's stereotypical portrayal of the black voodoo villain, and the negative representation of a cosmopolitanized, that is to say globalized, voodoo culture, both ultimately defeated by the white masculinity that the Bond persona embodied; he thus reasserted the film's Western perspective in spite of its apparent cosmopolitan setting.

13 The second plenary session delivered by Deborah Shaw (University of Portsmouth). Entitled "Unorthodox Jewish Cosmopolitans on our Screens," it focused on the German 
American coproduction Unorthodox (Maria Schrader, 2020) distributed by Netflix, which recounts the story of Etsy, a young woman unhappily living a pre-arranged marriage, who flees the ultra-orthodox Hasidic community of Satmar in Brooklyn's Williamsburg (NY) to find a new life in the unorthodox, open, cosmopolitan Berlin. Shaw mentioned at the beginning of her talk the negative connotations of cosmopolitanism, as it was attributed to the Jews, demonized as "rootless parasites". In pointing up the Jewish ultra-Orthodox community as a transnational but insular ethnic and religious group, profoundly tied to the trauma of the Holocaust and often rejecting the outside world as dangerous and anti-semitic, the miniseries upholds a different interpretation of cosmopolitan identity. While the Hasidic community of Williamsburg belongs to a devout world with strict rules against personal freedom, Berlin's secular, global, and multicultural community depends on a hopeful cosmopolitan canopy, mainly represented by the inclusive queer-LGBT community. An essential point of her talk centered on the issue raised by a Netflix production addressed to an international audience, depicting the actual city of Berlin as an idealized space of inclusion but also preoccupied with the accusation of inaccuracy in the depiction of the Hasidic community coming from the Jews of New York.

In the "Cosmopolitan Cities" panel, Sven Weidner (University of Bamberg) analyzed the representation of New York and Los Angeles as two megacities usually connected with the concept of cosmopolitanism in the US context; focusing on Cosmopolis (David Cronenberg, 2012) and Knight of Cups (Terrence Malick, 2015), Weidner questioned the discourses on cosmopolitanism employed by these two films through the use of audiovisual strategies, used by the filmmakers to explore the social, economic, and psychological meanings connected to these two cosmopolitan cities. New York City was also at the heart of Céline Murillo's talk (Université Sorbonne Paris Nord). Focusing on the No Wave movement's relationship with the Lower East Side in the 1970s, Murillo argued that even if the area was a hotbed able to attract many artists and filmmakers from various foreign countries, No Wave preferred to take into account the idea of foreignness - such as, for instance, in The Foreigner (Amos Poe, Ivan Kral, 1978) - instead of proclaiming itself as a champion of cosmopolitan values supposedly produced within a cosmopolitan milieu. Drawing from Nikos Papastergiadis's theories (2019) on aesthetic cosmopolitanism, Gracie Vaughn Joy (University College London) examines Pocketful of Miracles (Frank Capra, 1961) as a film that questions the exquisitely aesthetic standards imposed by the cosmopolitan elite living in New York in the 1960s; studied alongside Lady for a Day (Capra, 1933), Pocketful of Miracles offered an occasion to understand the evolution of the image of a cosmopolitan New Yorker and its possible limits, providing a tongue-in-cheek commentary on the privileged few.

The "International Reception" panel was the fourth to focus on borders, this time in relation to global audiences. It opened with a talk by Melvyn Stokes, who compared the reception of three iconic films (The Birth of a Nation, D. W. Griffith, 1915; Modern Times, Charlie Chaplin 1936; Gone With the Wind, Fleming et al., 1939) in the US, Britain and France; Stokes was able to show how, depending on the context of the reception these films first came out in (some of them were censored in France) the reading of these works had been completely different and how they had become "iconic" in each of these national contexts, while carrying various, and sometimes contradictory ideologies. A similar approach was taken by Stefano Darchino (Université Paris 8), who compared the reception of the Blues Brothers (John Landis, 1980) in Italy and in the US, showing how it was highly praised by Italian critics while US-American reviews largely 
criticized the film's racist and offensive depiction of the Blues movement. Finally, Emmanuel Plasseraud (Université Bordeaux Montaigne) offered a chronological discussion of US-American reception theories and Hollywood's endeavor to achieve the creation of a "Citizen of the world" type of film.

In the fifth panel devoted to borders, "Science Fiction at the Border," speakers were analyzed the geographical and/or psychological experience of border-crossing in science fiction film and series. Luis Freijo (University of Birmingham) discussed Sense8 (Netflix, 2015-2018) from the perspective of Frontier theory and cosmopolitan philosophy; in the TV series, he argued, the constant state of violence typical of the western frontier is applied to the urban context of the eight global cities to depict their racism, corporate business corruption, and drug dealing. Freijo further explained how the sensates embodied a different kind of cosmopolitanism, where respect for differences, hybridity, and collectivism can be championed against unethical and economic forms of globalization. Marianne Kac-Vergne (Université de Picardie Jules Verne, Amiens) studied the US-Mexico border-crossing in the Terminator franchise; she traced an evolution from Terminator 2 (James Cameron, 1991), in which Mexico represents a place of escape for outlaws in the tradition of the Western, to Terminator: Dark Fate (Tim Miller, 2019) where the crossing of the border, shown from the other side, followed the path of immigrants looking for freedom in the US. Despite the utopian discourse on multicultural aspects transcending the division imposed by the border, the speaker showed how Mexican identity was still tied to a stereotyped version of an underdeveloped country. Finally, Olga Thierbach-McLean (Independent scholar) dwelled on the tendency of US cyberpunk cinema to draw on Asian motifs to manifest anxiety about Asia's technological and economic growth. She argued productions of the 1980s onwards - Blade Runner (Ridley Scott, 1982), The Matrix Trilogy (The Wachowskis, 1999-2003), Cloud Atlas (The Wachowskis 2012), Ghost in the Shell (Rupert Sanders, 2017), Blade Runner 2049 (Denis Villeneuve 2017) and Mr. Robot (USA, 2015-2019) - testify to an increase in the curiosity for Asian lifestyles, mostly seen as a dynamic symbol of the future, though remaining statically codified in a confused form of hybrid Orientalism or in a monolithic idea of "Asianness" that catalyzed fears of a dystopian future.

In the "Cosmopolitan Encounters" panel, Carolina Amaral and Vitor Medeiros (Universidade Federal Fluminense) analyzed Hill of Freedom (Hong San-soo, 2014) as a film that reinterprets the trope of the romantic comedy, with a cosmopolitan character wandering around the insulated neighborhood of Bukchon (Seoul); the film, they argued, exemplifies the possible outcomes produced by a connection between a traditional place and cosmopolitan hopes and behaviors. Drawing on Beck and BeckGernsheim (2014), Manuela Ruiz (Universidad de Zaragoza) analyzed Lion (Garth Davis, 2016) and And Breathe Normally (Isold Uggadóttir, 2018) as attempts to answer questions about romance and parenthood from a cosmopolitan perspective; focusing mainly on spaces, Ruiz studied the use of intertwined spatialities through paradigms such as enclosure, virtual geography, and contrasting locations, giving an impression of a fluctuating domain through which ethical, social, and affective matters are constantly interconnected. Finally, Andrea Regueira Martín (Universidad de Zaragoza) analyzed Party Girl (Daisy von Scherler Mayer, 1995) and God's Own Country (Francis Lee, 2017) as two instances in which a romantic relationship develops between a local resident and an immigrant actually lead, through romance, to a positive encounter inviting the 
locals to acknowledge their flaws and to find the necessary resources to lead their juvenile personality into adulthood.

The "Cosmopolitan Imaginations" panel opened with Zachary Baqué's (Université Toulouse - Jean Jaurès) investigation into the cosmopolitan fantasies of documentary movies made by the United States Information Agency, which were used as propaganda to depict the US as an open, multicultural nation, and promote this image abroad. Through an analysis of different productions of the USIA, either following a US leader on diplomatic journeys (Invitation to India, Invitation to Pakistan) or displaying through split screens or fast editing the various aspects of American lifestyle (Eulogy to 5:02, Grand Central Market), Baqué showed how this governmental instance privileged the idea of US-American Cosmopolitanism as "salad bowl" rather than "melting pot," keeping different cultures alive instead of assimilating them as one. Zsolt Györi (University of Debrecen) then discussed the cosmopolitan identity of Guy Ritchie's gangster movie heroes, who refuse to go with the flow and create a marginalized, yet cross-cultural community celebrating non-conformity in order to empower themselves. Hervé Mayer (Université Paul Valéry Montpellier 3) echoed Toulza's criticism of Live and Let Die, offering the same kind of remarks on the attempt but ultimate failure of a cosmopolitan approach in the MCU blockbuster Black Panther (Ryan Coogler, 2018); although, unlike Live and Let Die, the heroes and most of the protagonists of Black Panther are African or African-American, Mayer's detailed analysis of the setting, costumes and music revealed that the amalgam of African cultural objects and symbols actually harmed the movie's intention to displace the hero in another cultural context and reasserted once again an inescapable Eurocentrism.

In the "Reframing Cosmopolitan Tensions through Horror" panel, Christophe Chambost (Université Bordeaux Montaigne) analyzed Guillermo Del Toro's Cronos (1993), Blade II (2002) and The Strain (FX, 2014-2017) as metaphors of the limits of cosmopolitanism, as a possible form of standardization rejecting otherness; these films represent the deadly vampiric cannibalization of differences as a trope for the corrupting influences of capitalism. Still, the presence of transnational intertextual references (Bakhtinian heteroglossia, the motifs of baroque, magical realism) in Del Toro's movies were also scrutinized by Chambost as instances of the value of Mestizaje resisting against the domination imposed by Anglo-American capitalism. Ismael Ibánez (Universidad de Zaragoza) read the film Us (Jordan Peele, 2019) through Ulrich Beck's theory of global threats, arguing that the film was a valid instance of the paradoxical coexistence of modernity, progress, and risk. Finally, Kristian Feigelson (Sorbonne Nouvelle Paris 3) outlined the evolution of the idea of cosmopolitanism from its initial negative connotation (antisemitism) to the 1960s, when the concept acquired different declinations; while the US culture long preferred the "multicultural," Asia persisted in using the universal connotation. Feigelson concluded on the Asian resistance to blend the indigenous interpretation of modernity with the westernization of the continent.

In the "Transnational Authorship" panel, Andrés Bartolomé (Universidad de Zaragoza) analyzed Carnage (Roman Polanski 2011) from a cosmopolitan theory perspective, arguing that despite the film's utopian features, the handling of cinematic space tended to problematize the overtly optimistic reading of the film, furnishing a reminder of the gap between our cosmopolitan dreams and the collective project that was actually taken forward. In "Beyond Western Hegemonies", Maria Luna (Universidad Pompeo Fabra - Universitat Autònoma de Barcelona) examined EU coproductions in Colombia 
and how these transnational dynamics operated a transformation of the Colombian emergent film industry through European film festival exhibitions; she offered interactive maps as an analytical method to study the relationship between transnational exchanges and isolated locations of film production. Finally, Martin Knust (Linnæus University Växjö) dealt with the cosmopolitan potential of the movie soundtrack, arguing that if instrumental music had always been considered as a universal language, there were also many instances of musical compositions that had strict local connotations (which is the case of provincialism in country and folk music or the tendency of European composers working in Hollywood-Max Steiner, Erich Wolfgang Korngold, and, later on, Hans Zimmer-to maintain a close connection with their European backgrounds and national identities). Knust argued that the cosmopolitan potentials occurred mainly at the reception phase, in the audience's capacity to bond with otherness and create a new cosmopolitan openness.

The $26^{\text {th }}$ SERCIA Conference embraced the cosmopolitan aspirations of cinema and television through a wide range of areas, methods, and approaches. The first impression was that cinema, since its inception, had evolved with filmmakers, actors, screenwriters or technicians who gradually abandoned familiar frames of reference and national contexts in order to create a cosmopolitan imagination, a deterritorialized space able to blur boundaries between people, goods, values, and projects. Traveling actors, cosmopolitan filmmakers, global blockbusters, and transnational coproductions have contributed to the production of a cosmopolitan/global audience, who also experience collective visions projected beyond their native geographical territory. The analysis of international distributions also requires a study of reception in a globally scattered audience, while an overview of the panels showed how some cinematic genres could be explicitly related to cosmopolitan visions: Western or PostWestern, science fiction, horror, documentary, comedy and romcom. The conference successfully highlighted the multilayered and broad spectrum of fields and themes connected with the moral, social, cultural, and political frameworks of cosmopolitanism: language and translation, transnational feminist studies, transnational queer studies, ecological visions, the relationship between Western and Eastern worlds. By resorting to a particular methodology of spatial analysis and border theory, the many talks offered a better understanding of cosmopolitan dynamics, tackling spaces and places, which manifested the crucial role of borderlands and cosmopolises in identifying cosmopolitan behavior and practices. Indeed, in borderlands and cosmo-cities, as well as in productions trying to include a cosmopolitan perspective all around the world, the uncertainty between an idealistic interpretation emphasizing positive encounters, tolerance and acceptance, and a negative representation highlighting the limits of the global masquerade, most often remains, making the field of cosmopolitan research a fruitful and complex ground for further discussions to take place. 
INDEX

Subjects: Film, TV, Video

Keywords: cosmopolitanism, cosmopolitan, border, border-places, cities, global, national, transnational, industry, reception, distribution, cinema, seriality, series, TV, media, film, Hollywood, genre, Western, Post-Western, comedy, science fiction, horror, documentary, ecology, feminism, postfeminism, language, translation, star, celebrity, authorship Mots-clés: cosmopolitanisme, cosmopolite, frontière, espace frontalier, ville, mondialisation, national, transnational, industrie, réception, distribution, cinéma, sérialité, series, télévision, média, films, Hollywood, genre, western, post-western comédie, science fiction, horreur, documentaire, écologie, féminisme, postféminisme, langage, traduction, star, célébrité, auteurisme

\section{AUTHORS}

\section{COSTANZA SALVI}

Universidad de Zaragoza

Doctoral student

costanzasalvi@gmail.com

MARINE SOUBEILLE

Université Paul Valéry Montpellier 3

Doctoral student

marine.soubeille@gmail.com 